\title{
ЧТО И КАК ВЗАИМОСВЯЗАНО В ЭКОНОМИКЕ? ПОИСК ОТВЕТОВ ЧЕРЕЗ ЕСТЕСТВЕННЫЕ ЭКСПЕРИМЕНТЫ
}

\author{
В.А. Воробьев, А.А. Кравченко, Т.Л. Майборода*
}

Представлен вклад Д. Карда, Д. Ангриста и Г. Имбенса в разработку и применение новых способов выявления причинно-следственных связей в экономической науке. Через проведение естественных экспериментов Кард, в частности, эмпирически выявил и дал численную оценку влиянию уровня минимальной заработной платы и иммиграции на рынок труда, что доказало продуктивность данного подхода. Ангрист и Имбенс подняли использование инструментальных переменных на новый уровень путем оценки локального среднего эффекта воздействия, что позволило преодолеть ряд методологических проблем. Рассмотрены ключевые научные работы лауреатов, особенности методологии и ее критика, внеэкономическое применение экспериментов.

Ключевые слова: естественные эксперименты, исследование с акцентом на дизайн, локальный средний эффект воздействия, инструментальные переменные, рынок труда, минимальная заработная плата, иммиграция, отдача от образования, профсоюзы.

JEL-классификация: B41, C90, I26, J21, J51, J61, J65, R23.

DOI: $10.46782 / 1818-4510-2021-4-4-26$

Материал поступил 16.11.2021 2.

Нобелевская премия по экономике в 2021 г. присуждена Дэвиду Карду за «эмпирический вклад в экономику труда», а также Джошуа Д. Ангристу и Гвидо В. Имбенсу за их «вклад в методы анализа причинно-следственных связей». В рейтинге $\mathrm{RePEc} / \mathrm{IDEAS}$ эти ученые находятся в топ50 исследователей в области экономики, что свидетельствует об их значительном вкладе в экономическую науку и высокой востребованности опубликованных ими работ ${ }^{1}$.

\section{От теории - кестественным әкспериментам и квазиэкспериментам}

От теории к эмпирике. До Второй мировой войны экономическая наука в знаalldetail.html чительной степени сохраняла свой описательный характер ${ }^{2}$, а ключевыми критериями верности гипотезы выступали логичность, непротиворечивость, последовательность аргументов и ссылки на авторитетные источники. В послевоенный период в экономических исследованиях расширяется использование сложного математического аппарата и математических моделей ${ }^{3}$. Дж. Стиглер и его соавторы проанализировали статьи в пяти ключевых экономичес-

\footnotetext{
${ }^{2}$ В том смысле, в каком использовал данное понятие А. Маршалл в «Основах экономической науки».

${ }^{3}$ В 1948 г. выходит в свет первое издание «Экономики» П. Самуэльсона, в котором применен новый экономический язык, основанный на математике, единственно возможный, по мнению автора, для изложения основных положений экономической теории (Самуэльсон П. 2002. Основания экономического анализа. Санкт-Петербург: Экономическая школа. 604 с.).
}

* Воробьев Виктор Анатольевич (vorobiev_v@bseu.by), доктор экономических наук, профессор, Белорусский государственный экономический университет (г. Минск, Беларусь). https://orcid.org/0000-0001-8285-7304;

Кравченко Александр Александрович (wildsent@gmail.com), кандидат экономических наук, доцент, Центр поведенческой экономики «МеMicroMacro» (г. Минск, Беларусь). https://orcid.org/0000-0001-8386-0687;

Майборода Татьяна Леонидовна (mtv_1@tut.by), кандидат экономических наук, доцент, Белорусский государственный экономический университет, Центр поведенческой экономики «МеMіcroМасrо» (г. Минск, Беларусь). https://orcid.org/0000-0002-9589-8620 
ких журналах с 1892 по 1990 г. и определили, что доля преимущественно описательных статей сократилась с 95\% (1892-1922 гг.) до 33\% (1962-1963 гг.), а в 1989-1990 гг. такие публикации составили менее $5 \%{ }^{4}$. Математизация экономической науки проявилась и в том, что понятие «модель» стало наиболее часто встречающимся в названиях и описаниях экономических статей с 1960 по 2010 г. ${ }^{5}$. Аналитической приемлемости отдается явное предпочтение над описательной точностью, без этого развитие теории признается невозможным ${ }^{6}$.

Одновременно усиливается критика экономической теории за абстрактность и игнорирование реальности. В. Леонтьев в 1971 г. отмечал, что слабое и к тому же медленно развивающееся эмпирическое основание не может выдержать веса бурно растущей надстройки «чистой», или умозрительной, экономической теории ${ }^{7}$. И в 1970-х годах начинается серьезный сдвиг в этой науке. На смену преимущественно теоретическим работам приходят эмпирические исследования. За период с 1963 по 2011 г. доля сугубо теоретических статей в таких журналах, как American Economic Review, Journal of Political Economy и The Quarterly Journal of Economics, сократилась с 52,2 до $27,9 \%$, в то время как удельный вес «эмпирических» публикаций вырос с 47,8 до $63,9 \%$ соответственно ${ }^{8}$. Эта тенденция затронула не только такие разделы экономической науки, как прикладная микроэкономика и экономика труда, где традиционно много внимания уделялось реальным процессам, но и теоретическую микрои макроэкономику, общественные финансы (Angrist, Azoulay, Ellison, Hill, Lu, 2017).

Расширение эмпирических исследований в экономике стало доступным благо-

${ }^{4}$ Stigler G., Stigler S., Friedland C. 1995. The Journals of Economics. Journal of Political Economy. Vol. 103. No 2. PP. $331-359$.

${ }^{5}$ Kosnik L. 2015. What Have Economists Been Doing for the Last 50 Years? A Text Analysis of Published Academic Research from 1960-2010. Economics: The Open-Access, OpenAssessment E-Journal. Vol. 13. PP. 1-38.

${ }^{6}$ Фридмен М. 1994. Методология позитивной экономической науки. THESIS. Вып. 4. С. 20-52.

7 Леонтьев В. 1990. Экономические эссе. Теории, исследования, факты и политика. Москва: Политиздат. 415 с.

${ }^{8}$ Hamermesh D.S. 2013. Six Decades of Top Economics Publishing: Who and How? Journal of Economic Literature. Vol. 51. No 1. PP. 162-172. даря огромному массиву собираемой информации, компьютеризации, упростившей математические расчеты, а также возросшему спросу на эти исследования со стороны экономических и политических агентов, принимающих решения в области экономической политики. Популярность доказательного менеджмента как внутри коммерческих организаций, так и среди политических акторов создала ситуацию, при которой ключевым критерием убедительности стала не столько виртуозность в риторике и логичности изложения, сколько умение оперировать данными.

О пользе такого перехода свидетельствует возросший авторитет экономической науки среди других общественных наук. Анализ, проведенный Дж. Ангристом и его соавторами, показал, что экономические исследования с высокой долей эмпирического анализа являются одними из наиболее цитируемых в 7 из 15 рассмотренных ими научных дисциплинах ${ }^{9}$ (Angrist, Azoulay, Ellison, Hill, Lu, 2020). Важность эмпирических исследований обусловила возрастание требований к их достоверности, а также к математическим и статистическим навыкам экономистов-ученых. Соответствующим образом изменяется и ландшафт образовательных программ при их подготовке ${ }^{10}$.

\section{Проблемы обсервационных исследова-} ний. Обсервационные исследования в процессе расширения столкнулись с проблемами в использовании эконометрических методов. Обозначим лишь три из них: установление наличия причинно-следственной связи; определение направления этой связи, если она есть; проблема эндогенности.

Общеизвестно, что корреляция не означает каузальность, т. е. даже если две переменные изменяются одновременно, это еще не свидетельствует о наличии между ними причинно-следственной связи. Так, T. Виген на своем сайте ${ }^{11}$ собирает наибо-

9 Анализировались издания по следующим научным дисциплинам: антропология, политология, психология, социология, математика, медицина, физика, статистика, общественное здравоохранение, исследование операций, информатика, менеджмент, маркетинг, финансы, бухгалтерский учет.

10 Petkus M., Perry J., Johnson B. 2014. Core Requirements for the Economics Major. The Journal of Economic Education. Vol. 45. No 1. PP. 56-62.

${ }^{11}$ URL: http://tylervigen.com. См. также: Vigen T. 2015. Spurious Correlation. New York: Hachette Books. 208 p. 
лее интересные корреляции, которые не могут рассматриваться как каузальность. Например, к ним относятся корреляции между объемом потребления маргарина и долей разводов в США $(r=0,992)$ или возрастом мисс Америка и количеством смертельных случаев от ожогов паром $(r=0,87)$. И если в приведенных примерах достаточно применить логику, чтобы понять, что выделенные явления вряд ли связаны между собой, то в других случаях это может быть не так очевидно. Например, есть ли связь между количеством преступлений и числом иммигрантов в стране, доходом семьи и продолжительностью образования детей, сокращает ли наличие смертной казни уровень преступности, влияет ли количество детей на доходы домашних хозяйств, и т. д.

Обсервационные исследования сталкиваются и со сложностью определения направления предполагаемой причинно-следственной связи. Например, если наблюдается корреляция между увеличением минимальной заработной платы и ростом уровня безработицы в стране, то нельзя утверждать, что такова каузальная обусловленность. Минимальная заработная плата вводится (или изменяется) по определенным причинам, среди которых может быть и рост безработицы. Например, циклический спад сопровождается сокращением занятости и снижением реальной заработной платы неквалифицированных работников. Будут усиливаться требования к повышению минимальной заработной платы для борьбы с бедностью. Если политики начнут действовать в соответствии с такими требованиями, то увеличение минимальной заработной платы явится следствием безработицы и роста бедности, а не их причиной.

И еще одна проблема, с которой сталкиваются исследователи, - ненаблюдаемые факторы одновременно могут влиять на зависимые и независимые переменные (проблема эндогенности). Классическим примером является анализ воздействия количества лет обучения на уровень будущего дохода. Скорее всего, будет наблюдаться положительная корреляция между этими переменными, однако есть факторы, которые могут быть не учтены, но окажут существенное влияние на результат. Например, люди, которые дольше учатся, возможно, имеют лучшие врожденные навыки (обладают большей усидчивостью, отличной памятью), что облегчает для них процесс получения знаний; или состоятельные родители могут обеспечить своим детям более поздний выход на рынок труда. Очевидно, что и без дополнительных лет обучения такие дети, скорее всего, будут получать большие доходы. Поэтому непосредственная корреляция между количеством лет обучения и доходом может показать искаженный peзультат.

Осознание этих и других проблем и желание их избежать привели к изменению дизайна эмпирических исследований. Начиная с 1990-х годов в них все чаще используются экспериментальные и квазиэкспериментальные методы ${ }^{12}$. Если увеличение эмпирических публикаций получило название «эмпирический сдвиг» (empirical turn), то новая тенденция была названа Дж. Ангристом и Й. Пишке «революцией достоверности» (credibility revolution) (Angrist, Pischke, 2010).

Экономические эксперименты. Если раньше отличие экономики от естественных наук связывалось с невозможностью осуществления экономических экспериментов $^{13}$, то сегодня последние стали не только важным экономическим инструментом, но и своего рода эталоном для эмпирических исследований. Дж. Харрисон и Дж. Лист выделяют четыре вида экономических экспериментов: лабораторный эксперимент (lab experiment); артефактный полевой эксперимент (artefactual field experiment); рамочный полевый эксперимент (framed field experiment) и естественный полевой эксперимент (natural field experiment) (Harrison, List, 2004). Эти виды экспериментов объединяются тремя ключевыми параметрами: искусственное происхождение и, как следствие, относительно высокий уровень контроля со стороны

12 К квазиэкспериментальным методам Дж. Ангрист и Й. Пишке относили такие методы, как «разность разностей» (difference-in-differences), «дизайн разрывной регрессии» (regression discontinuity design), естественные эксперименты и рандомизированнные котролируемые испытания (РКИ) (Angrist, Pischke, 2010).

${ }^{13}$ Samuelson P., Nordhaus W. 1985. Economics. Twelfth edition. New York: McGraw-Hill. 950 p. 
руководителя (дизайнера) эксперимента над факторами воздействия; участники эксперимента распределяются в контрольную группу и группу воздействия ${ }^{14}$ случайным образом; результаты воздействия оцениваются в сравнении с контрольной группой ${ }^{15}$.

Ключевое преимущество экономических экспериментов по сравнению с обсервационными исследованиями - возможность выделить и доказать наличие причинной связи между явлениями ${ }^{16}$. Авторы экспериментов могут создать такую среду, при которой все факторы, кроме представляющего интерес, остаются контролируемыми (их влияние или нивелируется, или не оказывает воздействия на результат). Частично это достигается за счет случайного распределения участников или случайного назначения им воздействия ${ }^{17}$. Таким образом решаются проблемы эндогенности и сложности выделения причинно-следственной связи между рассматриваемыми переменными, а сам дизайн эксперимента может быть организован так, чтобы четко определить направление выявленной связи.

Важнейшей характеристикой экономических экспериментов является внутренняя и внешняя валидность. Внутренняя валидность отражает, насколько дизайн исследования действительно позволяет выявить взаимосвязи изучаемых явлений. Высокая внутренняя валидность предполагает большую степень уверенности, что зависимая переменная изменяется под воздействием

14 Группа воздействия объединяет участников эксперимента, для которых изменяют интересующий дизайнера исследовательский параметр. Контрольная группа включает участников, которые не подвергаются интервенции, или к ним применяется другое значение исследовательского параметра. Например, если необходимо выяснить, какие виды поощрений влияют лучше на мотивацию работников - материальные или нематериальные, то группой воздействия могут выступать те испытуемые, к которым будут применять или материальную, или нематериальную мотивацию, а контрольной группой - те, к кому никакой мотивации применяться не будет. Возможен также вариант, когда контрольной группой будет одна из групп воздействия (например, для параметра материального поощрения контрольной группой может стать группа с нематериальным поощрением, и наоборот).

${ }^{15}$ Freedman D., Pisan R., Purves R. 2007. Statistics. New York: W.W. Norton \& Company, 2007. 715 p.

${ }^{16}$ Freedman D. 2006. Statistical Models for Causation: What Inferential Leverage Do They Provide? Evaluation Review. Vol. 30. No 6. РP. 691-713.

17 Рандомизация позволяет достигнуть ситуации, при которой распределение ненаблюдаемых характеристик между группами воздействия и контрольной группой будет сбалансированным. именно выбранной переменной, а не других факторов. Внешняя валидность означает вероятность получения таких же или схожих результатов, если поменять пул участников или сами участники окажутся в другой среде. Если лабораторные экономические эксперименты позволяют добиться большей внутренней валидности в ущерб внешней, то естественные полевые эксперименты достигают высокого уровня внешней валидности, однако демонстрируют меньшие возможности контроля со стороны дизайнера и, как следствие, уровень внутренней валидности ниже.

Таким образом, один из способов обойти ряд проблем, присущих эмпирическим исследованиям, - это разработать и провести эксперимент. Однако данный метод не является универсальным средством, поскольку значительная часть вопросов в экономике не может быть изучена таким образом. Планирование и проведение одних экспериментов является слишком дорогостоящим мероприятием, другие не могут быть выполнены по этическим соображениям. Если при попытке ответить на вопрос, требующий эмпирической проверки, не представляется возможным проведение непосредственного экономического эксперимента, то текущей практикой является выстраивание такого дизайна исследования, «как будто» необходимый или очень похожий эксперимент был уже реализован, т. е. исследователи прибегают к естественным экспериментам или квазиэкспериментам.

Естественные эксперименты и квазиэксперименты. В отличие от рассмотренных выше экономических экспериментов, естественные эксперименты не создаются искусственно. Они связаны со сложившейся в экономике, стране, регионе, на предприятии или рынке ситуацией, в рамках которой, как и в обычном эксперименте, можно определить влияние интересующего фактора, выделив группу воздействия и контрольную группу и сопоставив их между собой. Чаще всего такая ситуация является результатом действия политических или социальных сил, однако может появляться и под воздействием природных катастроф. Еще одно сходство с обычными экспериментами заключается в рандомиза- 
ции формирования групп воздействия и контроля, т. е. в отсутствии дополнительных факторов, которые могли бы повлиять на распределение участников, а следовательно, исказить возможные результаты.

Классическими примерами таких естественных экспериментов являются лотереи для отбора в армию, которые проводились правительством США среди людей призывного возраста во время Вьетнамской войны, а также в Аргентине. В США в 1969 г. каждому из дней года в случайном порядке с помощью лототрона были присвоены номера от 1 до 366. Призыву в первую очередь подлежали мужчины 1945-1950 гг. рождения, родившиеся в дни, которым выпали наименьшие номера (Angrist, 1990). В Аргентине действовала похожая процедура, только номера не были привязаны к датам рождения, а соответствовали трем последним цифрам в номере паспорта, а от выигравшего номера зависел не только факт призыва, но и род войск, а следовательно, и срок службы.

Такие лотереи являются естественным экспериментом, поскольку цель их проведения (набор призывников в армию) не связана с теми или иными научными задачами. Однако в результате этой процедуры у исследователей появляются данные, которые позволяют сравнить между собой группу воздействия (мужчин, служивших в армии) и контрольную группу (тех, кто данную службу не проходил) и проанализировать, как военная служба влияет на те или иные переменные.

Исследование Дж. Ангриста показало, что в начале 1980-х, спустя много лет после завершения службы во Вьетнаме, заработные платы белых ветеранов были примерно на 15\% меньше, чем доходы сверстников, в войне не участвовавших (Angrist, 1990). С. Галиани с соавторами на основании аргентинских данных также продемонстрировали, что служба отрицательно сказывается на призванных в армию ${ }^{18}$. В зрелом возрасте они с большей вероятностью были склонны к нарушению закона, особенно к финансовым махинациям и мошен-

${ }^{18}$ Galiani S., Rossi M., Schargrodsky E. 2011. Conscription and Crime: Evidence from the Argentine Draft Lottery. American Economic Journal: Applied Economics. Vol. 3. No 2. PP. 119-136. ничеству, и получали более низкую заработную плату. При этом такие последствия обнаружены не только для когорт, проходивших службу в военное время, но и для тех, кто призывался в мирное время.

Далеко не всегда получается обнаружить ситуацию, при которой участники группы воздействия и контрольной группы распределены таким явно случайным образом. Тогда ученые пытаются найти событие, при котором распределение произошло схожим со случайным образом, или доказать, что оно таковым является. Различие между чистым рандомизированным и «похожим на случайное» распределениями по группам заключается в том, что последнее требует дополнительных исследований и доказательств, т. е. не может рассматриваться как рандомизированное априори.

Таким образом, естественные эксперименты являются прежде всего обсервационными исследованиями, так как данные получаются не за счет контролируемого воздействия со стороны ученого, а являются следствием события, не зависящего от его решения. Но при этом, как и в настоящих экспериментах, выводы делаются на основании сравнения результатов групп воздействия и контрольной группы, участники между которыми были распределены случайным образом.

Дж. Ангрист называет естественные эксперименты квазиэкспериментами, рассматривая эти понятия как синонимы (Angrist, 1990), однако ряд авторов считает целесообразным разделять данные понятия (Dunning, 2012). Ключевым отличием квазиэкспериментов от естественных является неслучайность распределения участников между сравниваемыми группами. Анализируемые события в квазиэкспериментах часто обусловлены политическими решениями, которые могут не являться случайными. Например, рост минимальной заработной платы в определенном регионе может быть следствием сложившейся ситуации на рынке труда непосредственно в этом регионе, а увеличение расходов на правоохранительные органы является ответом на ухудшение криминогенной ситуации. В том и в другом случае решения не были случайными, а следовательно, и сами 
события не могут рассматриваться в качестве естественных экспериментов. Квазиэксперименты полезны для доказательства причинно-следственных связей, однако, как и со «схожим со случайным» распределением, требуют дополнительных исследований и обоснований.

Метод разности разностей. Один из методов, используемый как в обычных экономических, так и в естественных и квазиэкспериментах, - метод «разность разностей» ${ }^{19}$. Несмотря на применение во многих экономических исследованиях, наибольшую популярность он получил в экономике труда, где одним из первых его использовал Р. Лестер в 1946 г. при изучении влияния минимальной заработной платы на занятость. Часть работ Д. Карда, принесших ему известность, построена именно на применении данного метода. Чтобы использовать метод разности разностей, исследователь должен сделать и обосновать важное допущение, что развитие ситуации в группе воздействия, если бы интервенция не состоялась, было бы точно таким же, как и в контрольной группе, а это, в свою очередь, накладывает существенные ограничения на выбор данной группы.

Инструментальные переменные. Одним из методов, тесно связанным с естественными экспериментами, является использование инструментальных перемен-

${ }^{19}$ Предположим, в регионе А произошел рост расходов на содержание правоохранительных органов и через некоторое время количество преступлений в нем сократилось. Исходя из данной информации нельзя утверждать, что именно рост расходов привел к снижению преступности, ведь могло произойти и общее сокращение преступности в стране. В связи с этим сравнения только по одному и тому же региону до и после интервенции могут показать смещенные результаты. Одним из вариантов решения проблемы является выбор в качестве контрольной группы региона В, где расходы за этот же период не изменились, и сравнение уровней преступности между двумя регионами. Такой подход тоже не лишен недостатков, поскольку в регионе В, выбранном для сравнения, может изначально наблюдаться как более, так и менее высокий уровень преступности, а следовательно, будут получены заниженные или завышенные оценки влияния расходов. Использование метода разности разностей предполагает сбор данных по группе воздействия и контрольной группе (регионы А и В) до и после роста расходов в регионе А и проведение расчетов в два этапа: первый этап - рассчитывается разность между средними показателями по каждой из групп в каждом из периодов (в нашем примере это изменения в уровнях преступности в регионах А и В за исследуемый период); второй этап - рассчитывается разность полученных на первом этапе результатов (от изменения уровня преступности в регионе А отнимается изменение уровня преступности в регионе В). Полученные результаты и являются искомыми. ных. Когда изучается комплексный вопрос, например о влиянии доходов людей на их политические предпочтения, простая корреляция покажет искаженные результаты из-за проблемы эндогенности и неопределенности направления причинно-следственной связи. Возможно, политические предпочтения человека определяют круг его общения, карьерную траекторию и его будущие доходы. Один из способов избежать данной неопределенности - найти фактор, который, с одной стороны, тесно связан с интересующей исследователя переменной (доход), а с другой, напрямую не связан и не влияет через другие переменные на результирующий показатель (политические предпочтения). Такой фактор получил название инструментальной переменной, а ее использование позволяет ответить на ряд вопросов, уходя от некоторых эконометрических проблем ${ }^{20}$.

Поиск инструментальной переменной является нетривиальной задачей. В частности, заменить показатель дохода на чтото, не связанное с политическими предпочтениями, затруднительно, поскольку занимаемая должность, самозанятость или наемный труд, место проживания и т. д. могут являться следствием или быть тесно связанными с идеологическими воззрениями индивида. В своем исследовании влияния дохода на политические предпочтения Д. Доэрти с соавторами в качестве инструментальной переменной использовали денежный выигрыш в лотерею (эта переменная непосредственно влияла на доходы человека, однако была экзогенной по отношению к его политическим воззрениям $)^{21}$.

${ }^{20}$ В частности, инструментальная переменная в отличие от заменяемой переменной не должна коррелировать с ошибками в регрессии.

21 Чтобы оценить влияние дохода на политические предпочтения, авторы провели интервью с 342 людьми, выигравшими в лотерею между 1983 и 2000 гг. в одном из восточных штатов США. Параллельно проводился опрос широкой общественности. Сравнение победителей, дифференцированных по сумме выигрыша, показало, что богатство увеличивает негативное отношение к налогам на наследство и к государственному перераспределению доходов, но мало влияет на отношение к экономическому расслоению или к государственному социальному страхованию. В целом полученные данные свидетельствуют об ограниченном воздействии изменения доходов на политическое мировоззрение. Doherty D., Gerber A., Green D. 2006. Personal Income and Attitudes Toward Redistribution: A Study of Lottery Winners. Political Psychology. Vol. 27. No 3. PP. 441-458. 
Инструментальные переменные были известны до 1990-х годов и использовались в трудах экономистов (например, «гипотеза избыточного труда» Т. Шульца). Но с 1990-х годов данный метод применяется значительно чаще, а выбор инструментальных переменных становится все более обоснованным. Работа Д. Ангриста и А. Крюгера (Angrist, Krueger, 1991) явилась поворотной и установила современные стандарты использования метода инструментальных переменных ${ }^{22}$. Эти исследователи не только предложили замену изначальному показателю, но и провели дополнительный анализ, подтверждающий их базовые предпосылки. Авторы продемонстрировали статистически и графически, что выбранная переменная действительно может использоваться в качестве прокси и полученные с ее помощью выводы отражают исследуемые причинно-следственные связи. Одновременно они указали и на ограничения по ее использованию ${ }^{23}$. В дальнейшем следование данному подходу позволило значительно повысить внутреннюю валидность эмпирических исследований, однако усилилась проблема внешней валидности.

22 Здесь и ниже используется: Answering Causal Questions Using Observational Data. Scientific Background on the Sveriges Riksbank Prize in Economic Sciences in Memory of Alfred Nobel 2021. URL: https://www.nobelprize.org/uploads/2021/10/ advanced-economicsciencesprize2021.pdf

${ }^{23}$ Ангрист и Крюгер обнаружили, что дата рождения человека может повлиять на продолжительность среднего образования. Это связано, во-первых, с тем, что в США на уровне штатов законодательно устанавливается возраст, до достижения которого ученикам не разрешается бросать школу, и, во-вторых, все дети, родившиеся в определенном году (не существенно, в январе или декабре), идут в школу одновременно. Это означает, что учащиеся, родившиеся в начале года, достигают возраста возможного прекращения обучения раньше других, и часто этим пользуются. Квартал рождения был предложен авторами в качестве инструментальной переменной, заменяющей количество лет обучения. Он влияет на продолжительность образования, но не оказывает прямого влияния на заработную плату. Ангрист и Крюгер определили, что те, кто родился в I квартале, имели меньшую среднюю продолжительность обучения (на 0,15 года), чем родившиеся в IV квартале. В среднем доходы родившихся в IV квартале превышали доходы рожденных в I квартале на $1,4 \%$. Отношение между разницей в доходах и разницей в обучении - это инструментальная оценка показателя отдачи от обучения. В данном конкретном случае она равна 0,089 , или доход от дополнительного года обучения составляет примерно 9\%. Полученные результаты относятся в основном к тем, кто с высокой вероятностью бросил бы школу при первой возможности. Вполне возможно, что отдача от обучения для этой части населения не является репрезентативной для всего населения. Здесь исследователи сталкиваются с проблемой оценки локального среднего эффекта воздействия (Angrist, Krueger, 1991).
Локальный средний эффект воздействия. Результат естественного эксперимента (например, установленное влияние службы в армии на заработную плату) предполагает одновременный ответ на вопрос: на какую группу населения полученные выводы могут быть распространены? Так как в качестве инструментальной переменной использовался «выигрыш» в лотерею, а не непосредственная служба в армии, то среди тех людей, которые принимали участие в лотерее и чьи номера выпали, часть могла не попасть в армию по состоянию здоровья или по другим причинам, а часть обладателей не выпавших номеров захотела добровольно пойти на службу. Будут ли распространяться и на них выводы, сделанные авторами?

В большинстве естественных экспериментов группа воздействия и контрольная группа делятся не по факту наличия интересующего параметра (например, служба в армии или завершение обучения в школе по достижении определенного возраста), а исходя из возможности возникновения данного параметра (например, выпадение номера в драфт-лотерее или квартал рождения индивида). Такой подход получил название «намерение лечить» (intention-to-treat) ${ }^{24}$.

В медицине, когда врач не может точно проконтролировать, кто из пациентов следовал его предписаниям, а кто нет, эффективность лечения оценивается не с помощью сопоставления результатов тех, кто безукоснительно следовал указаниям и кто их полностью проигнорировал (чаще всего выделить эти категории не представляется возможным), а путем сопоставления результатов тех, кто получил данное предписание, и тех, кто его не получал. При этом в обеих группах могут присутствовать четыре категории людей. Две из них не меняют своего поведения: «всегда принимающие» (always-takers) - те, кто использует лечение вне зависимости от того, получили они предписание врача или нет; «всегда отка-

${ }^{24}$ В англоязычных экспериментальных исследованиях часть терминологии позаимствована из медицины. Так, группы, на которые направлены интервенции, называются «группами лечения» (treatment group), а синонимом интервенций выступает слово «лечение» (treatment). Мы же будем использовать термины «группа воздействия» и «интервенции», которые чаще встречаются в научной русскоязычной литературе. 
зывающиеся» (never-takers) - те, кто всегда отказывается от лечения вне зависимости от наличия предписания. Две другие категории людей меняют свое поведение в зависимости от рекомендаций врача: «исполняющие» (compliers) руководствуются предписанием врача, если они даны, и откажутся от лечения, если такого предписания не было; «бунтари» (defiers) отказываются применять лечение, если получили предписание, и обязательно применят лечение, если предписания не было.

Аналогичные категории людей могут существовать и в случае анализа немедицинского естественного эксперимента, особенно с использованием инструментальных переменных. Если нельзя четко идентифицировать, к какой из них принадлежит каждый из анализируемых субъектов, то определение точного эффекта воздействия для всей совокупной выборки представляется затруднительным, а чаще всего и невозможным. Заслуга Г. Имбенса и Дж. Ангриста состоит в том, что, используя допущения о монотонности и исключаемости ${ }^{25}$, они показали, как определить эффект воздействия путем сопоставления средних результатов контрольной группы и группы воздействия. Однако размер эффекта можно определить не для всей совокупной выборки, а только для ее части, а именно для «исполняющих». Если для описания размера воздействия для случайного индивида из выборки используется понятие «средний эффект воздействия» (average treatment effect), то эффект интервенции для «исполняющих» получил название «локальный средний эффект воздействия» (local average treatment effect - LATE).

Таким образом, выявленный в ходе естественного эксперимента размер влияния интервенций применим сугубо к тем людям, кто менял свое поведение под воздействием данных интервенций. Так, негативные эффекты от службы в армии были определены именно для мужчин, которые

25 Предположение об исключаемости подразумевает, что результат зависит от самого воздействия, а не от его назначения. Предположение о монотонности - при добавлении субъекта в группу воздействия результат должен или оставаться постоянным, или монотонно изменяться (или прирастать, или сокращаться, но не должно наблюдаться то приращение, то убывание результата). самостоятельно не пошли бы в армию, если бы не выпал их номер в лотерее. Аналогичным образом эффект от дополнительных лет образования, обнаруженный Д. Ангристом и А. Крюгером (Angrist, Krueger, 1994), применим в полной мере к воспользовавшимся возможностью бросить среднюю школу после определенного возраста. Чаще всего идентифицировать средний эффект воздействия для всей выборки не представляется возможным, однако благодаря использованию LATE у исследователей, с одной стороны, появилось больше возможностей отвечать на интересующие их вопросы, а с другой - возникло понимание, как лучше интерпретировать полученные результаты.

\section{Реалистичная модель рынка труда: вклад Д. Карда}

Начиная с 1980-х годов в большинстве промышленно развитых стран наблюдается резкое усиление неравенства в распределении доходов (намного большее в США и Великобритании, чем в странах континентальной Европы ${ }^{26}$. Для понимания причин этого процесса и совершенствования экономической политики необходима реалистичная модель рынка труда, раскрывающая влияние различных факторов на спрос и предложение труда и, соответственно, на заработную плату и занятость. Значительный вклад в анализ рынка труда внес Д. Кард, который использовал естественные эксперименты для определения влияния минимальной заработной платы, иммиграции, инвестиций в образование, профсоюзов, системы социального страхования на занятость и доходы.

Минимальная заработная плата и занятость. Классическая модель конкурентного рынка труда предполагает, что увеличение минимальной заработной платы выше ее равновесного уровня приведет к росту издержек фирм, снижению спроса на труд и сокращению занятости ${ }^{27}$ (прежде всего занятости молодых и менее квалифицированных работников). До начала

${ }^{26}$ Пикетти Т. 2015. Капитал в ХХІ веке. Москва: АД Маргинем Пресс. 592 с.

${ }^{27}$ Stigler G. 1946. The Economics of Minimum Wage Legislation. American Economic Review. Vol. 36. No 3. PP. $358-365$. 
1990-х годов анализ взаимосвязи минимальной заработной платы и занятости был основан на использовании данных временных рядов ${ }^{28}$, и определение причинно-следственных эффектов в данном контексте являлось чрезвычайно сложной задачей. В исследованиях Д. Карда и его последователей гибко контролировались общие временные тенденции, четко указан источник изменения заработной платы и исчерпывающе описан подход, используемый для оценки эффекта занятости.

В своей первой статье по данной проблеме Д. Кард с целью выявления причинно-следственных зависимостей сравнил изменения заработной платы и занятости в Калифорнии, где минимальная заработная плата повысилась в 1988 г. с 3,35 до 4,25 долл. США в час ${ }^{29}$, с данными по другим штатам, в которых политика минимальной заработной платы не менялась ${ }^{30}$ (Card, 1992a). В результате не было получено свидетельств снижения занятости среди подростков или относительной потери рабочих мест в розничной торговле (где высок удельный вес низкооплачиваемых работников $)^{31}$.

28 Ч. Браун, К. Гилрой, А. Коэн обобщили результаты этих исследований: повышение минимальной заработной платы на $10 \%$ снижает занятость подростков (16-19 лет) до $3 \%$, занятость молодых людей (20-24 года) также падает, но на меньшую величину. Направленность воздействия минимальной заработной платы на занятость взрослых не установлена. Brown C., Gilroy C., Kohen A. 1982. The Effect of The Minimum Wage on Employment and Unemployment. Journal of Economic Literature. Vol. 20. No 2. PP. 487-528.

29 В течение предыдущего года $11 \%$ работников и $50 \%$ подростков в Калифорнии зарабатывали меньше нового минимума, установленного в штате.

30 Основным препятствием, с которым сталкиваются исследователи многих стран, изучающие влияние минимальной заработной платы на занятость, является универсальность минимальной ставки для большинства работников. Однако в США в конце 1980-х годов законодатели нескольких штатов отреагировали на десятилетнее снижение федеральной минимальной реальной заработной платы, установив ее выше федерального уровня. Это дало возможность изучить причинно-следственную взаимосвязь минимальной заработной платы и занятости. Для оценки изменений в соотношении численности занятых и численности населения в Калифорнии («группа воздействия») как следствия роста минимальной оплаты труда Д. Кард в «контрольную группу» включил Аризону, Флориду, Джорджию, Нью-Мексико и Техас, в которых заработная плата не менялась, но все остальные факторы, влияющие на занятость, были такими же.

${ }_{31}$ Между 1987 и 1989 гг. разрыв в общем соотношении занятых и населения между Калифорнией и штатами «контрольной группы» увеличился на $0,6 \%$. Однако фак-
Еще в одной работе Д. Кард проанализировал последствия изменения в 1990 г. национального стандарта минимальной заработной платы в США $\mathrm{A}^{32}$ : «эффект воздействия» по штатам варьировался в зависимости от доли работников, изначально получавших заработную плату в размере меньшем, чем новый минимум ${ }^{33}$ (Card, 1992b). Если бы произошло снижение занятости в штатах с низкой заработной платой ${ }^{34}$, это подтвердило бы гипотезу о негативном влиянии на рынок труда роста минимальной заработной платы. Д. Кард установил, что повышение минимальной заработной платы привело к увеличению средней заработной платы подростков, но не получил доказательств существенного снижения уровня их занятости.

Л. Кац и А. Крюгер, применившие аналогичную методологию в своем исследовании, получили похожие результаты (Katz, Krueger, 1992). Они использовали в качестве идеи для исследования тот факт, что повышение минимальной заработной платы должно по-разному отразиться на издержках фирм в зависимости от доли занятых на них работников, которые раньше получали зарплату ниже нового минимума. Изучая рестораны быстрого питания в Teхасе до и после повышения федеральной минимальной заработной платы в США в 1990 и 1991 гг., Кац и Крюгер установили, что занятость в этих заведениях повысилась, при этом она увеличилась больше в тех фирмах, где рост издержек в связи с повышением минимальной заработной платы был выше.

тический рост занятости подростков в Калифорнии за этот период составил 4,1\%, т. е. повышение минимальной заработной платы привело не к снижению, а увеличению занятости. Наблюдаемые изменения в занятости контрастируют с прогнозами, основанными на исследованиях временных рядов, которые предполагают сокращение занятости подростков на 3-8\% в результате произошедшего повышения минимальной заработной платы на $27 \%$.

32 В начале апреля 1990 г. Конгресс США (впервые за почти десять лет) увеличил федеральную минимальную заработную плату с 3,35 долл. США до 3,80 и затем с 1 апреля 1991 г. - до 4,25 долл. США в час.

33 Повышение федеральной минимальной заработной платы в США в 1990 г. предположительно затронуло более 50\% подростков в некоторых южных штатах и только $5 \%$ в отдельных штатах на северо-востоке страны.

${ }^{34}$ В эту группу штатов вошли Западная Вирджиния, Южная Каролина, Кентукки, Теннеси, Миссисипи, Арканзас, Луизиана, Оклахома, Монтана, Вайоминг, Нью-Мексико, Северная Дакота и Южная Дакота. 
В исследованиях, основанных на панельных данных, не всегда ясно, почему в одних штатах минимальная заработная плата была увеличена, а в других - нет. Возможно, на региональные рынки труда влияли разные факторы. В «идеальном» варианте желательно, чтобы перспективы трудоустройства в анализируемых штатах оставались неизменными и варьировалась лишь минимальная заработная плата. Для устранения влияния других факторов Кард и Крюгер сравнили два соседних региона в граничащих друг с другом штатах, в которых применялась разная политика минимальной заработной платы, но факторы, определяющие экономическое развитие этих регионов, были схожими (Card, Krueger, 1994). Свидетельств сокращения занятости также не получено ${ }^{35}$.

Экспериментальные данные, противоречащие устоявшейся теоретической модели рынка труда, стимулировали новые исследования как в США, так и в других странах ${ }^{36}$. Результаты многих из них были аналогичными ${ }^{37}$. В научной литературе даны следующие объяснения

35 Изучалось влияние повышения минимальной заработной платы в штате Нью-Джерси с 4,25 до 5,05 долл. США в час в апреле 1992 г. Обследованию подверглись 410 ресторанов быстрого питания в Нью-Джерси («группа воздействия») и восточной Пенсильвании (контрольная группа), где минимальная заработная плата оставалась на уровне 4,25 долл. США в час после ее повышения в НьюДжерси. В среднем стартовая заработная плата в НьюДжерси увеличилась на 11\% больше, чем в Пенсильвании, но при этом занятость в Пенсильвании снизилась, а в НьюДжерси наблюдался небольшой рост. Сравнение ресторанов, в которых увеличились издержки на оплату труда, с ресторанами, в которых оплата и ранее была выше 5,05 долл., также не показало сокращения занятости в первых в сравнении со вторыми.

36 Card D., Krueger A. 2000. Minimum Wages and Employment: A Case Study of the Fast-Food Industry in New Jersey and Pennsylvania: Reply. The American Economic Review. Vol. 90. No 5. PP. 1397-1420; Dube A. 2019. Impacts of Minimum Wages: Review of the International Evidence. London: HM Treasury. URL: https://assets.publishing.service.gov.uk/ government/uploads/system/uploads/attachment_data/file/ $844350 /$ impacts_of_minimum_wages_review_of_the_i nternational_evidence_Arindrajit_Dube_web.pdf; Manning $\bar{A}$. 2021. The Elusive Employment Effect of the Minimum Wage. Journal of Economic Perspectives. Vol. 35. No 1. PP. 3-26.

37 П. Вольфсон и Д. Белман представили мета-анализ 37 исследований, осуществленных в течение 15 лет в США, для оценки эластичности занятости по минимальной заработной плате. Они обнаружили, что диапазон эластичности сместился к нулю в сравнении с 1970-ми годами. Подростки и работники заведений общественного питания составили половину их выборки. Wolfson P., Belman D. 2019. 15 Years of Research on U.S. Employment and the Minimum Wage. Labour. Vol. 33. No 4. PP. 488-506. выявленной зависимости: общие затраты на рабочую силу растут медленнее, чем повышается минимальная заработная плата (фирмы одновременно уменьшают стоимость других составляющих социального пакета, экономят на найме и обучении персонала в связи со снижением текучести кадров); рост минимальной заработной платы стимулирует повышение производительности труда; в условиях неэластичного спроса на услуги, предоставляемые ресторанами быстрого питания, повышение минимальной заработной платы может быть перенесено на потребителей без существенного снижения спроса на продукцию и падения занятости; в условиях монопсонии влияние повышения минимальной заработной платы на занятость неоднозначно из-за уравновешивающего воздействия одновременно на спрос и предложение на рынке труда.

Итак, многие из проведенных за последние 30 лет исследований, вопреки предсказаниям классической модели конкурентного рынка труда, показали несущественное влияние минимальной заработной платы на занятость и сняли ограничения на использование политики повышения минимальной заработной платы для сокращения неравенства в распределении доходов $^{38}$. Если в 1994 г. ОЭСР настойчиво рекомендовала странам не применять государственное регулирование минимальной заработной платы для борьбы с бедностью и переориентироваться на политику прямых выплат, то в 2018 г. эта организация согласилась с тем, что умеренная и хорошо продуманная политика минимальной заработной платы содействует росту занятости и доходов ${ }^{39}$. Вопрос лишь в том, насколько может быть повышена минимальная зара-

38 С этим выводом согласны далеко не все. Например, Д. Ноймарк и П. Ширли утверждают, что в экономической литературе на сегодняшний день преобладают негативные оценки влияния минимальной заработной платы на занятость менее квалифицированных работников. Этот вывод сделан на основе опроса авторов 57 статей по данной проблематике. Neumark D., Shirley P. 2021. Myth or Measurement: What Does the New Minimum Wage Research Say about Minimum Wages and Job Loss in the United States? National Bureau of Economic Research. Working Paper 28388. URL: http://www.nber.org/papers/w28388

${ }^{39}$ Manning A. 2021. The Elusive Employment Effect of the Minimum Wage. Journal of Economic Perspectives. Vol. 35. No 1. PP. 3-26. 
ботная плата без существенного снижения занятости ${ }^{40}$.

\section{Влияние иммиграции на рынок труда.}

Сопровождается ли приток мигрантов значительным снижением заработной платы, ухудшением перспектив трудоустройства местных работников и ростом бедности - этот вопрос давно и широко обсуждается во многих странах. Для ответа на него необходимо знать, дополняют или замещают на релевантном рынке труда иммигранты местных жителей; повлияют ли шоки со стороны предложения труда на спрос на труд, т. е. появятся ли в регионах с большим притоком иммигрантов новые фирмы с технологиями, лучше соответствующими навыкам иммигрантов; вызовет ли приток иммигрантов изменения в спросе на товары и услуги и отразится ли это на перспективах трудоустройства местных работников. Негативный взгляд на иммиграцию, базирующийся на мнении, что она дорого обходится жителям принимающей страны, доминировал в экономике труда до начала 1990-х годов и имеет немало сторонников и сегодня ${ }^{41}$.

В своей первой работе по данной проблематике Д. Кард изучил уникальное событие в истории рынка труда США - так называемый «лодочный подъемник Мариэль» ${ }^{42}$. Кард проанализировал уровни заработной платы и занятости в Майами и четырех городах сравнения ${ }^{43}$ до и после дан-

40 В 2019 г. появилась петиция, которую подписали 134 американских экономиста (среди них - А. Дитон, П. Даймонт, Д. Асемоглу, Д. Катлер, Эм. Саэс), в поддержку повышения минимальной заработной платы в США в два раза (до 15 долл. США в час) к 2024 г. Авторы отмечают, что проведено много тщательных академических исследований, показавших, что предыдущее умеренное повышение минимальной заработной платы практически не оказывало отрицательного воздействия на занятость лиц с низкой заработной платой. URL: https://www.epi.org/ economists-in-support-of-15-by-2024/

${ }^{41}$ Например, Дж. Борхас утверждает, что иммиграция в США в период с 1980 по 2000 г. снизила среднюю заработную плату местных жителей примерно на $3 \%$, а заработную плату наименее квалифицированных работников - на 9\%. Borjas G. 2014. Immigration Economics. Cambridge, Massachusetts: Harvard University Press. 296 p.

42 В период с мая по сентябрь 1980 г. с согласия правительства около 125000 кубинцев покинули страну через порт Мариэль и на лодках отправились в США, а половина из них поселилась в столичном регионе Флориды. Всего за несколько месяцев рабочая сила Майами выросла на $7 \%$, а увеличение предложения низкоквалифицированной рабочей силы было еще большим.

${ }^{43} \mathrm{~B}$ контрольную группу естественного эксперимента были включены Атланта, Лос-Анджелес, Хьюстон и Там- ного события (Card, 1990). Несмотря на массовый приток неквалифицированных мигрантов, исследователь не обнаружил свидетельств того, что существенно снизились уровень заработной платы и занятость местных неквалифицированных работников (в том числе афроамериканцев) или прежних кубинских иммигрантов. Им предложены два объяснения тому, почему заработная плата и безработица в регионе слабо отреагировали на иммиграционное событие: во-первых, миграция в Майами жителей и иммигрантов прошлых лет из других регионов США сократилась ${ }^{44}$; вовторых, из-за своей иммиграционной истории Майами имел промышленную структуру ${ }^{45}$, способную поглотить большой приток неквалифицированной рабочей силы. Но распространить результаты данного естественного эксперимента на другие рынки труда нельзя, поскольку во многом они определены тем, что Майами принимал иммигрантов именно с Кубы ${ }^{46}$.

Последующее исследование в этом направлении Д. Кард выполнил совместно с Дж. Алтонджи (Altonji, Card, 1991). Они представили дополнительные данные о влиянии иммиграции на рынок труда. Эффекты от иммиграции оценивались по 120 крупным городам США: изучалось изменение уровней заработной платы и занятости менее квалифицированных местных жителей (либо в разрезе между городами, либо в пределах городов с течением времени) в зависимости от доли и квалификационного состава иммиг-

па-Сент-Питерсберг. Такой выбор Д. Кард обосновывает следующими обстоятельствами: в этих городах проживало относительно много темнокожих работников и латиноамериканцев и наблюдалась похожая с Майами модель экономического роста в период с 1976 по 1984 г.

${ }^{44}$ С 1970 по 1980 г. население Майами росло со скоростью 2,5\% в год, в то время как население остальной части Флориды - со скоростью 3,9\%. После 1 апреля 1980 г. темпы роста населения в Майами замедлились до 1,4\% в год, а в остальной части штата - только до $3,4 \%$.

45 Для региона была характерна высокая концентрация текстильной и легкой промышленности, ориентированной на низкоквалифицированный труд. В этих отраслях в Майами было занято 5,5\% рабочей силы по сравнению с 2,3\% по стране.

46 На протяжении двух десятилетий до «лодочного подъемника» Майами поглощал непрерывный поток кубинских мигрантов, а после 1980 г. принял большое количество никарагуанцев и жителей других стран Центральной Америки. Этим он отличается от большинства американских городов. 
рантов на местных рынках труда. Использовались данные переписей населения США в 1970 и 1980 гг. Получены следующие результаты: наблюдалось незначительное вытеснение местных жителей из отраслей, в которых интенсивно использовался низкоквалифицированный труд; увеличение на 1\% доли иммигрантов снижало заработную плату менее квалифицированных местных жителей на $1,2 \%{ }^{47}$.

Теоретическая модель, используемая Алтонджи и Кардом для описания влияния иммиграции на внутренний рынок труда, характеризовалась следующими новыми свойствами: это модель со стороны спроса, в которой прибытие иммигрантов моделируется как положительный шок предложения рабочей силы; рабочая сила разделяется по квалификационному признаку, а не по национальному происхождению: предполагается, что рынок труда в каждом городе состоит из квалифицированных и неквалифицированных работников и иммиграция вызывает сдвиг долей этих групп в зависимости от качественного состава прибывающих иммигрантов ${ }^{48}$.

Анализ сдвига долей был в дальнейшем усовершенствован Д. Кардом при оценке влияния иммиграционных потоков на рынок труда с привлечением данных переписи США 1990 г. (Card, 2001a). Сделаны три важных вывода. Во-первых, приток новых иммигрантов в отдельные города в период 1985-1990 гг. не привел к возникновению значительных компенсирующих потоков мобильности (переезду в другие регионы) местных жителей или более ранних иммигрантов из тех же профессиональных групп. Поэтому в городах, которые принимали большое количество новых иммигрантов, как правило, значительно увеличивалась доля низкоквалифицированных работников. Во-вторых, сдвиги долей различных профессиональных групп в насе-

47 При оценке этого результата необходимо учитывать, что общенациональная тенденция к значительному сокращению занятости в 1970-1980-х гг. меньше проявилась в городах с высокой долей иммигрантов в составе рабочей силы: некоторые отрасли с низкой заработной платой смогли выжить только в этих городах.

48 В более ранних исследованиях подгруппы иммигрантов не разграничивались: изучалась корреляция заработной платы и занятости местного населения с изменениями доли иммигрантов в общей рабочей силе. лении города связаны с изменениями относительной занятости. Оценка методом инструментальных переменных показала, что приток новых иммигрантов в 19851990 гг. снизил относительный уровень занятости низкоквалифицированных местных работников и более ранних иммигрантов примерно на 1\% (до 3\% в городах с очень высоким уровнем иммигрантов, таких как Лос-Анджелес или Майами $)^{49}$. В-третьих, приток иммигрантов в конце 1980-х годов снизил заработную плату менее квалифицированных работников сферы услуг в городах с высоким уровнем иммиграции не более чем на $3 \%$ (эффект в других городах и для других профессиональных групп намного меньший).

В более поздней работе Д. Кард изучает воздействие иммиграции на неравенство в распределении доходов среди местного населения США и приходит к выводу, что существенного влияния нет ${ }^{50}$. Но если оценивать уровень неравенства в оплате труда среди всех работников (включая иммигрантов), то он выше, чем был бы в отсутствие иммиграции. Однако эффект относительно невелик: на иммиграцию приходится относительно небольшая доля роста общего неравенства в заработной плате с 1980 по 2000 г. - от 4 до 6\%.

Основной результат исследований проблем иммиграции, полученный Д. Кардом, состоит в том, что баланс экономических выгод и затрат (даже для местных работников, непосредственно конкурирующих с иммигрантами) является более положительным, нежели можно было бы предположить.

Исследования иммиграции путем сравнения функционирования рынков труда в разных городах или штатах подверглись критике со стороны Дж. Борхаса, Р. Фримена и Л. Каца ${ }^{51}$. Они указывают на три проблемы: во-первых, иммиграционные потоки приводят к значительным компен-

49 Оценки с использованием метода наименьших квадратов в два-три раза меньше.

${ }^{50}$ Card D. 2009. Immigration and Inequality. American Economic Review. Vol. 99. No 2. PP. 1-21.

51 Borjas G., Freeman R., Katz L. 1996. Searching for the Effect of Immigration on the Labor Market. American Economic Review. Vol. 86. No 2. PP. 246-251; Borjas G. 2014. Immigration Economics. Cambridge, Massachusetts: Harvard University Press. 296 p. 
сирующим перемещениям местных жителей, которые уезжают в ответ на приток иммигрантов; во-вторых, перекрестная корреляция между притоком иммигрантов и заработной платой местных жителей может быть смещена в сторону повышения из-за роста регионального спроса на товары и услуги, что увеличивает заработную плату и привлекает иммигрантов; в-третьих, в долгосрочной перспективе влияние увеличения предложения рабочей силы в конкретном городе, вызванное иммиграцией, может быть распределено на всю экономику через межрегиональную торговлю ${ }^{52}$.

В последние годы было проведено много дополнительных исследований проблемы влияния иммиграции на местные рынки труда. Среди новых результатов можно отметить следующие: во-первых, миграция негативно влияет на перспективы занятости прежних иммигрантов, в то время как местное население получает выгоды от новых иммигрантов; во-вторых, местные работники избегают негативных последствий, занимая рабочие места, требующие коммуникативных навыков, где меньше конкуренция со стороны иммигрантов ${ }^{53} ;$ в-третьих, технологические инвести-

52 Д. Кард обращает внимание на три методологические неточности в анализе Дж. Борхаса: во-первых, капитал в нем рассматривается как фиксированная величина, что не соответствует действительности и искажает влияние иммиграции на местное население в долгосрочном периоде; во-вторых, у Борхаса трудовые услуги местных жителей и иммигрантов - совершенные субституты, в то время как на реальном рынке труда они являются несовершенными субститутами; в-третьих, если в литературе традиционно работники разделяются на две квалификационные группы (с уровнем образования, эквивалентным средней школе, и уровнем, эквивалентным колледжу), то модель Борхаса четырехгрупповая (он выделяет дополнительно группу бросивших среднюю школу и группу не завершивших обучение в колледже). При этом предполагается, что бросившие среднюю школу и выпускники средней школы имеют такую же степень взаимозаменяемости, как и выпускники средней школы и выпускники колледжей, что не соответствует эмпирическим данным. Поскольку среди иммигрантов высока доля бросивших обучение в школе, издержки иммиграции для местных работников, включенных в эту группу, искусственно завышаются. Card D. 2012. Comment: The Elusive Search for Negative Wage Impacts of Immigration. Journal of the European Economic Association. Vol. 10. No 1. PP. 211-215; Card D., Peri G. 2016. Immigration Economics by George J. Borjas: A Review Essay. Journal of Economic Literature. Vol. 54. No 4. PP. 1333-1349.

53 Дж. Пери и Ч. Спарбер документально подтвердили, что иммигранты, как правило, специализируются на видах занятости, в меньшей степени использующих языковые и коммуникативные навыки. Среди более молодых и менее образованных иммигрантов еще одним фактором ции приспосабливаются к притоку иммигрантов, что также снижает негативное воздействие на группы, наиболее затронутые иммиграцией.

Образование и сокращение бедности. Важным фактором повышения заработной платы и снижения бедности является образование. Но эмпирические исследования, осуществленные до 1990-х годов, связи между инвестициями в образование (направляемыми прежде всего на уменьшение размеров классов и повышение квалификации и заработной платы учителей) и его качеством (результатами стандартизированных тестов) практически не улавливали ${ }^{54}$. Широко распространилось мнение, что увеличивать финансирование государственных школ нецелесообразно.

Д. Кард и А. Крюгер в 1992 г. опубликовали две совместные работы, в которых данный подход был переосмыслен, при этом качество образования связывалось с успешностью работников на рынке труда, а не с результатами тестов. В первой статье оценивалось влияние соотношения учеников и учителей, средней продолжительности учебного года и относительной заработной платы учителей на отдачу от дополнительного года обучения для когорт мужчин, родившихся между 1920 и 1949 гг. (на основе данных переписи населения 1980 г. в США) (Card, Krueger, 1992a). Поскольку характеристики населения (доход и уровень образования родителей) и рынка труда (различающиеся по штатам факторы спроса и предложения) также влияют, наряду с качеством школьного образования, на доходы, Кард и Крюгер предложили «миграционный дизайн» (movers design) для разделения этих эффектов: сравнивались люди из одних возрастных когорт, проживавшие на момент наблюдения в одном штате, но родившиеся и учившиеся в разных штатах. Такой подход позво-

является правовой статус: многие из них нарушают иммиграционные законы и могут выполнять только ограниченный спектр работ, позволяющих эти законы обойти. Peri G., Sparber C. 2009. Task Specialization, Immigration, and Wages. American Economic Journal: Applied Economics. Vol. 1. No 3. PP. 135-169.

54 Hanushek E.A. 1986. The Economics of Schooling: Production and Efficiency in Public Schools. Journal of Economic Literature. Vol. 49. No 3. PP. 1141-1177. 
лил ответить на вопрос, больше ли отдача от дополнительных лет обучения у людей, выросших в штатах, где расходы на образование выше. Дополнительно были рассмотрены факторы, определявшие различия в отдаче от образования между последовательными возрастными когортами в отдельных штатах ${ }^{55}$. В итоге удалось подтвердить наличие причинно-следственной связи: качество образования влияет на производительность труда и отдачу от образования в будущем ${ }^{56}$. Но увеличение доходов при повышении качества образования не обязательно приводит к росту средней заработной платы (доходы более образованных работников могут расти за счет менее образованных). Кард и Крюгер, контролируя переменные различий между людьми, родившимися в разных штатах, доказали значительное положительное влияние качества школы как на среднюю продолжительность обучения, так и на последующие средние доходы от каждого года обучения.

В следующей совместной статье Кард и Крюгер проанализировали, как резкое сокращение между 1920 и 1950 гг. соотношения «ученики-учитель» на юге США ${ }^{57}$ повлияло на относительные доходы темнокожих и белых мужчин из разных когорт в восемнадцати сегрегированных штатах (Card, Krueger, 1992b). Используя информацию о лицах, переехавших в северные штаты, они показали, что отдача от образования действительно увеличилась с повышением его качества разрыв в заработной плате афроамериканцев и белых в период с 1960 по 1980 г. Значительно сократился.

При исследовании этого вопроса необходимо было разделить эффекты повышения качества образования и реализации

${ }_{55}$ Не были получены доказательства того, что отдача от образования связана с доходом или уровнем образования когорты родителей.

56 Уменьшение количества приходящихся на одного учителя учеников на пять человек привело к росту отдачи от дополнительного года обучения на 0,4 п. п.; повышение заработной платы учителей на $10 \%$ связано с увеличением отдачи от обучения на 0,1 п. п. Показатели доходов были также выше для выпускников школ из штатов с более высокой долей учителей-женщин.

57 Например, в 1920-х годах соотношение учеников и учителей в южных школах для темнокожих было на $50 \%$ выше, чем в школах для белых, в то время как средний учебный семестр был на 20\% короче. К концу 1950-х годов условия в школах для афроамериканцев и белых во многих южных штатах стали схожими. федеральной антидискриминационной политики, поскольку Закон о гражданских правах 1964 г. также сыграл важную роль в сокращении разрыва в заработной плате в США. Перекрестные показатели отдачи от образования по расе и региону рождения показали, что отдача от инвестиций в образование темнокожих южан выросла по сравнению как с белыми, родившимися на юге, так и черными мужчинами, родившимися на севере. Это доказывает, что рост отдачи от инвестиций в образование для афроамериканцев-южан был следствием улучшения качества школьного образования, а не только сокращения дискриминации темнокожих работников в масштабах всей экономики. Повышение относительного качества школьного образования для темнокожих работников южного происхождения объяснило четверть сближения относительных доходов афроамериканцев и белых, принадлежащих к когортам, родившимся в 1910-1919 и в 1940-1949 гг., и обеспечило 15-20\% общего роста относительных доходов темнокожих работников между 1960 и 1980 гг.

Позднее Д. Кард исследует такой экзогенный фактор школьного образования, как дистанционная близость колледжа ${ }^{58}$. Анализ влияния уровня образования на заработную плату молодых мужчин ${ }^{59}$ показывает, что выросшие в районах с расположенным поблизости колледжем имеют более высокий уровень образования и более высокие доходы. Это прежде всего касается мужчин из малообеспеченных семей, которые в противном случае завершили бы образование на относительно низком уровне. При этом оценка отдачи от года дополнительного образования на основе метода инструментальных переменных была большей (10-14\%), чем соответствующая оценка с применением метода наименьших квадратов $(7,3 \%)$.

В этой связи Кард отмечает: если конкретный естественный эксперимент затрагивает в основном людей с низким уровнем образования и этот уровень определен

${ }^{58}$ Card D. 1995. Using geographical variation in college proximity to estimate the return to schooling. URL: https:// www.nber.org/system/files/working_papers/w4483/w4483.pdf

59 Используются данные Программы Бюро статистики труда США «National Longitudinal Survey of Youth». 
не отсутствием способностей к продолжению образования, а высокими предельными издержками продолжения обучения, то оценки отдачи от обучения на основе метода инструментальных переменных превышают среднюю отдачу в популяции (Card, 1999). При таком сценарии политические инициативы, направленные на повышение уровня образования лиц из семей с низкими доходами, будут иметь значительную отдачу в плане сокращения бедности. Общий вывод, который можно сделать на основе тридцатилетних исследований данной проблемы, - инвестиции в образование влияют на результаты на рынке труда в промышленно развитых странах $^{60}$, и это влияние выше для лиц из неблагополучных семей.

\section{Влияние профсоюзов на неравенство} в оплате труда. До 1970-х годов в экономической литературе преобладала точка зрения, согласно которой деятельность профсоюзов усиливает неравенство в оплате труда. Работы Р. Фримена стали переломными во взглядах экономистов на эту проблему. Используя микроданные по вовлеченным и не вовлеченным в профсоюзы работникам, он показал, что профсоюзное движение в целом содействует сокращению неравенства доходов ${ }^{61}$.

В своей первой работе по данной проблематике Д. Кард изучил влияние профсоюзов на заработную плату и процесс отбора на рабочие места (Card, 1996). Он установил, что членство в профсоюзах в большей степени повышает заработную плату работников с низким уровнем квалификации, поэтому они скорее предпочтут предприятия, на которых действуют профсоюзы ${ }^{62}$. Важнейшее следствие этого вывода -

${ }^{60}$ Jackson K. 2019. Does School Spending Matter? The New Literature on an Old Question. Working Paper Series. Northwestern University. URL: https://www.ipr.northwestern.edu/ documents/working-papers/2019/wp-19-02.pdf

61 Фриман обнаружил, что примерно $20 \%$ роста неравенства в заработной плате среди мужчин с 1978 по 1988 г. можно объяснить снижением их участия в профсоюзной деятельности. Freeman R. 1980. Unionism and the Dispersion of Wages. Industrial Labor Relations Review. Vol. 34. No 1. PP.3-23.

62 Модель Карда оценивает влияние профсоюзного статуса на доходы работников, разделенных на пять квалификационных групп, с использованием большого набора панельных данных, сформированных на основе обследований населения 1987 и 1988 гг. Простые кросс-секто- различия в заработной плате между работниками разной квалификации, как правило, сокращаются на предприятиях, где созданы профсоюзы. Уменьшаются на них и различия в квалификации работников: поскольку высокопроизводительные работники с меньшей вероятностью захотят работать на предприятиях с профсоюзами, в то время как работодатели таких предприятий с меньшей вероятностью захотят нанять низкопроизводительных работников, будет привлечено больше работников со средним уровнем квалификации.

В более поздней работе Д. Кард использует микроданные обследования населения США за 1973-1974 гг. и 1993 г., чтобы оценить влияние членства в профсоюзах на уровень оплаты труда мужчин и женщин. Участие в профсоюзах мужчин за два десятилетия снизилось с 30,8\% в 1973-1974 гг. до 18,7\% в 1993 г., с большим падением вовлеченности низкооплачиваемых работников (Card, 2001b). Это привело к росту неравенства в оплате труда мужчин на 15-20\%. Членство в профсоюзах женщин с низкой заработной платой также снизилось, с более высокой заработной платой - увеличилось. В целом, участие женщин в профсоюзах не объясняет рост неравенства в оплате их труда за анализируемый период. В масштабах всей экономики увеличились различия в темпах роста неравенства между частным сектором, где вовлеченность в профсоюзное движение резко снизилась за анализируемый период, и государственным сектором, где она возросла: в государственном секторе наблюдается существенное замедление роста неравенства в оплате труда.

Несколькими годами позже Д. Кард, Т. Лемье, К. Ридделл представили новые доказательства взаимосвязи деятельности профсоюзов и неравенства в заработной плате для трех стран (Канада, США и Великобритания) за три десятилетия (Card, Lemieux, Riddell, 2004). Выбранные страны были потенциально ценными для изучения данной проблемы, поскольку для них ха-

ральные оценки разрыва в заработной плате в профсоюзном и непрофсоюзном секторах велики и положительны для низкоквалифицированных работников (35\% для принадлежащих к низшей квинтильной группе) и отрицательны для высококвалифицированных работников (-10\% для включенных в самый верхний квинтиль). 
рактерны децентрализованность коллективных переговоров между профсоюзами и работодателями, отсутствие механизмов распространения положений коллективных договоренностей за пределы профсоюзного сектора ${ }^{63}$. Это позволяет сравнить уровни заработной платы работников, вовлеченных в профсоюзы, и не охваченных коллективными договорами работников, и сделать вывод о влиянии профсоюзов на общее неравенство в заработной плате. К тому же США и Великобритания - это две страны с наименьшим участием работников в профсоюзах и в то же время с наибольшим ростом неравенства доходов.

Связывая снижение вовлеченности в профсоюзную деятельность с резким увеличением неравенства в заработной плате в рассматриваемых странах с 1970-х годов, Кард с соавторами нашли убедительное подтверждение тому, что профсоюзная деятельность благоприятна с социальной точки зрения, а продолжающийся спад профсоюзного движения нежелателен. Но они также отмечают, что сложно в целом оценить влияние профсоюзов на эффективность размещения ресурсов и экономические показатели из-за существования отрицательных внешних эффектов, связанных с их деятельностью.

Еще один важный вывод заключается в том, что влияние профсоюзов на структуру заработной платы в США, Канаде и Великобритании было удивительно похожим на протяжении 1970-1990 гг. Во всех трех странах доля вовлеченности в профсоюзы существенно снизилась. Для мужчин это привело к ослаблению уравновешивающего эффекта профсоюзов, что объясняет в значительной мере рост неравенства в оплате труда в США и Великобритании. Снижение членства женщин в профсоюзах было намного меньшим, чем

63 Подобную исследовательскую задачу сложнее решить в других странах (включая европейские государства и Австралию), потому что в них нет четкого разграничения между профсоюзным и непрофсоюзным секторами рынка труда. Коллективные переговоры в этих странах ведутся на отраслевом или более высоком уровне, и их положения формально распространяются на большую часть рабочей силы. Кроме того, во многих странах профсоюзы оказывают значительное влияние на политические решения (например, определение уровня минимальной заработной платы), которые напрямую влияют на результаты функционирования рынка труда. мужчин, и не усилило неравенство в оплате труда женщин. Уровень вовлеченности в профсоюзы также положительно влияет на разброс заработной платы по квалификационным группам.

Социальное страхование и рынок труда. В статье Д. Карда, Р. Четти, А. Вебера представлены результаты проверки моделей потребления домашних хозяйств (текущего и постоянного дохода) на основе данных рынка труда (Card, Chetty, Weber, 2007). Авторы применяют необычную меру потребления - интенсивность поиска работы. Чувствительность интенсивности поиска работы к текущим ликвидным активам физических лиц (наличным деньгам) работает в модели потребления таким же образом, как и чувствительность расходов домашних хозяйств на потребление к располагаемому доходу.

При оценке чувствительности поиска работы к наличным деньгам авторы использовали институциональные особенности рынка труда в Австрии: резкие разрывы, связанные с правом на получение выходного пособия для безработных (люди, имеющие трехлетний и выше стаж работы, будут получать это пособие, с более коротким стажем - нет) и с возможностью продления сроков получения страхового пособия по безработице для некоторых людей с 20 до 30 недель. Кроме того, исследователям были доступны данные о заработной плате и занятости всех работников частного сектора, что дало выборку из 650 тыс. лиц, потерявших работу. Резкий разрыв в условиях получения поддержки и большой размер выборки отличают данное исследование от традиционных, основанных на потреблении, - последние ограничиваются небольшими выборками и сталкиваются с трудностями в измерении краткосрочного потребления.

Были получены три эмпирически обоснованных результата.

1. Единовременное выходное пособие, равное двухмесячной заработной плате до налогообложения, снижает интенсивность поиска работы в среднем на 8-12\% (на эту величину продолжительность безработицы больше у тех, кто имеет право на пособие). Такая чувствительность к наличным день- 
гам несовместима с моделью постоянного дохода, в соответствии с которой агенты могут идеально сглаживать потребление.

2. Люди, имеющие льготное право на получение пособия в течение 30 недель, снижают интенсивность поиска работы в первые 20 недель на 5-9\% в сравнении с теми, кто может получать пособие только 20 недель. Такое дальновидное поведение несовместимо с моделью текущего дохода, в которой экономические агенты полностью близоруки при принятии решений.

3. Увеличение продолжительности поиска, вызванное программами социального страхования, практически не влияет на качество последующей работы и повышает в будущем среднюю заработную плату незначительно - менее чем на $1 \%$. Определение размера этого эффекта - важный нерешенный вопрос, представляющий дополнительный интерес.

Полученные оценки несовместимы с предсказаниями как модели постоянного дохода, так и модели текущего дохода. По мнению Д. Карда, Р. Четти, А. Вебера, модели с прогнозным поведением и ограниченным сглаживанием колебаний дохода, например модель буферного запаса (bufferstock model) Дитона ${ }^{64}$, с наибольшей вероятностью соответствуют полученным данным. Последующие исследования показали достоверность данных результатов и для экономик других стран.

Этот вывод важен для оценки эффективности налоговой политики и политики социального страхования: временное снижение налогов будет эффективным фискальным стимулом только тогда, когда домашние хозяйства чувствительны к наличным деньгам (текущему располагаемому доходу). Свидетельства несовершенного сглаживания предполагают, что временные налоговые изменения могут иметь существенные экономические последствия. Важную роль должны играть и программы временной поддержки доходов - страхование по безработице и краткосрочное социальное обеспечение. Но использование этих программ для дол-

${ }^{64}$ Deaton A. 1989. Saving and Liquidity Constraints. URL: https://www.nber.org/system/files/working_papers/ w3196/w3196.pdf госрочного повышения производительности труда нецелесообразно.

\section{Расширение применения әкспериментального подхода и метода инструментальных переменных}

Используемые лауреатами методы исследований нашли свое применение и за пределами экономики. Антропологи, географы, историки, юристы и политологи использовали естественные эксперименты для изучения различных тем: от последствий работорговли в Африке и степени снисходительности судей при вынесении решений о тюремных сроках до результатов расширения избирательного права ${ }^{65}$.

В политических исследованиях использование метода инструментальных переменных становится все более популярным, но таких работ немного. Можно выделить статью Мигеля и его соавторов, в которой был представлен естественный эксперимент, где процентное изменение количества осадков по сравнению с предыдущим годом выступает в качестве инструментальной переменной экономического роста, чтобы оценить влияние экономических условий на количество вооруженных конфликтов ${ }^{66}$. Исследователи обнаруживают значительную положительную взаимосвязь количества осадков и роста ВВП. Уравнение второго этапа оценивает влияние роста ВВП на уровень насилия. Полученные результаты показывают, что экономический рост значительно снижает вероятность гражданской войны ${ }^{67}$.

В историко-политическом исследовании изучалось влияние западногерманского телевидения на уровень общественной поддержки восточными немцами коммунистического режима ${ }^{68}$. Существует мнение, что демократические СМИ подрывают авторитарные режимы. Для выявления эффек-

65 Обзор применения экспериментов в социальных науках можно посмотреть здесь (Dunning T. 2012).

${ }^{66}$ Miguel E., Satyanath Sh., Sergenti E. 2004. Economic Shocks and Civil Conflict: An Instrumental Variables Approach. Journal of Political Economy. Vol. 112. No 4. PP. 725-753.

67 В своей критике данного исследования Даннинг утверждает, что рост в разных секторах экономики может иметь разное влияние на конфликты и что дождевые осадки скорее всего объясняют только вызванные экономическим ростом эффекты в сельскохозяйственном секторе (Dunning, 2012).

${ }^{68}$ Kern H., Hainmueller J. 2009. Opium for the Masses: How Foreign Media Can Stabilize Authoritarian Regimes. Political Analysis. Vol. 17. No 4. PP. 377-399. 
та воздействия иностранных СМИ на уровень поддержки режима гражданами использовалась такая инструментальная переменная, как близость проживания к Дрездену ${ }^{69}$. Вопреки интуитивным предположениям, восточным немцам с доступом к западногерманскому телевидению больше нравилась жизнь в Восточной Германии. Одно из предложенных объяснений состоит в том, что западногерманское телевидение в первую очередь выступало источником развлечения, что повышало уровень терпимости граждан к своему политическому режиму.

Любопытное историко-политико-экономическое исследование с помощью инструментальных переменных было проведено Д. Асемоглу, С. Джонсоном и Дж. Робинсоном. Они изучали влияние институтов, внедренных европейскими колонизаторами в разных странах, на текущий уровень ВВП на душу населения и текущий набор институтов через переменную смертности европейских поселенцев на новых землях ${ }^{70}$. Авторы смогли подтвердить гипотезу, что в тех странах или регионах, где поселенцам угрожала высокая смертность из-за неблагоприятного климата и болезней, была гораздо выше вероятность формирования «экстрактивных» институтов $^{71}$. В тех местах, где новым поселенцам было комфортно, вероятность формирования «Новой Европы» с импортом европейских институтов оказалась выше.

Исследование С. Галиани и Э. Шаргродского было построено на естественном эксперименте, изучающем наделение правами собственности в Аргентине ${ }^{72}$. В нача-

69 Чем ближе к Дрездену проживал человек, тем более сложным для него было получить доступ к иностранным СМИ, так как из-за особенностей географии и охвата вещанием в районе Дрездена не было возможности смотреть иностранное телевидение. Уровень поддержки замерялся через ответы в опросах и запросы на получение выездной визы в Западную Германию.

${ }^{70}$ Acemoglu D., Johnson S., Robinson J. 2001. The Colonial Origins of Comparative Development: An Empirical Investigation. American Economic Review. Vol. 91. No 5. PP. 1369-1401.

${ }^{71}$ Экстрактивные институты - те, которые способствуют максимальному выкачиванию ресурсов в пользу колонизаторов. В их рамках не обеспечивается защита прав собственности и подотчетность действий государства, так как в этом нет необходимости. Впоследствии это может отрицательно влиять на экономический рост в течение долгого времени (Робинсон Дж., Аджемоглу Д. 2018. Почему одни страны богатыле, а другие бедные. Происхождение власти, процветания и нищеты. Москва: АСТ. 692 с.).

${ }^{72}$ Galiani S., Schargrodsky E. 2010. Property rights for the poor: Effects of land titling. Journal of Public Economics. Vol. 94. No 9-10. PP. 700-729. ле 1980-х бедные жители Буэнос-Айреса самовольно захватили городские пустыри, разделив землю на равные участки между семьями. Закон, принятый в 1984 г., экспроприировал эту землю в пользу государства с намерением передать права собственности на нее тем же сквоттерам, но уже на законных основаниях. Однако некоторые из первоначальных владельцев обжаловали экспроприацию в суде, что привело к длительным задержкам в передаче им прав собственности на участки, в то время как права на другие участки сразу передали сквоттерам, не обратившимся в суд. В результате судебного иска были созданы группа воздействия (сквоттеры, которым права собственности передали) и контрольная группа (сквоттеры, которым передачу прав собственности отложили). Несмотря на то, что здесь не был задействован какой-нибудь инструмент рандомизации (лотерея, генератор случайных чисел, подбрасывание монеты и т. д.), распределение между группами можно рассматривать как «похожее на случайное».

Исследователи нашли существенные различия между этими группами: у семей, которые получили права собственности на землю сразу, уровень последующих инвестиций в жилье и уровень образования детей были выше, размер домохозяйств меньше. Интересным результатом этого естественного эксперимента является то, что не обнаружено отличие в уровне доступа к кредитным рынкам, что противоречит теории Эрнандо Де Сото о том, что бедные, обладая четко специфицированными правами собственности на имущество, смогут использовать его для обеспечения получения кредитов ${ }^{73}$. Наблюдались поведенческие особенности случайного распределения прав собственности: положительное влияние наделения правами собственности на самооценку индивидуальной эффективности. Например, сквоттеры, которые получили право собственности на землю, гораздо чаще соглашались с утверждением, что люди достигают успеха в жизни благодаря упорному труду.

${ }^{73}$ De Soto H. 1989. The Other Path: The Invisible Revolution in the Third World. Harpercollins. 271 p. 
Проведение естественных экспериментов все чаще применяется и в нашем научном пространстве. Особенно продуктивным их использование может оказаться в России, так как принятие отличающихся решений, стимулов и ограничений в разных регионах позволяет проследить их степень влияния $^{74}$. В одном из таких исследований анализируется эффект воздействия ограничений ночной торговли спиртным на объемы потребления алкогольных напитков ${ }^{75}$. Была выявлена положительная корреляция между количеством потребляемого алкоголя и продолжительностью разрешенного времени продаж спиртного в регионе. Полезным результатом для планирования антиалкогольных кампаний является полученное знание, что вечерние запреты более эффективны в сокращении количества потребляемого алкоголя, чем утренние.

\section{Критика методологчческих подходов}

Одним из ключевых пунктов критики предложенного нобелевскими лауреатами подхода стало опасение, что чрезмерная концентрация на внутренней валидности экспериментов приносит в жертву их внешнюю валидность.

А. Дитон, рассматривая темы экономического развития, оценки эффективности проектов, совершенствования экономической политики, отмечает, что наблюдается все более широкое использование РКИ, квазиэкспериментов, инструментальных переменных и естественных экспериментов (Deaton, 2010). Однако он сомневается в возможности получить полезные знания с применением этих подходов, так как результаты слишком узки и локальны, чтобы дать представление, что может выступить базой

${ }^{74} \mathrm{~B}$ частности, для России характерен довольно низкий темп вакцинации населения от коронавирусной инфекции и большое количество заболевших. Это заставило разные регионы принимать свои шаги по сдерживанию распространения болезни: от жестких ограничений на перемещение и посещение публичных мест до разнообразных стимулов в виде денежных подарков, скидок, лотерей и т. д. Сбор данных о динамике вакцинации и заболеваний после введения таких мер может дать ценную информацию об их сравнительной эффективности.

${ }^{75}$ Колосницына М.Г., Хоркина Н.А., Ситдиков М.Т. 2017. Ограничения торговли и потребления алкоголя: о результативности государственной политики. Проблемы прогнозирования. № 5. С. 116-128. для экономической политики. Нет никаких оснований утверждать, что данные, собранные и проанализированные в рамках экспериментов, в том числе естественных, обладают лучшим качеством или достоверностью, чем данные, полученные при использовании структурных моделей и других более традиционных подходов. Дитон предлагает сосредоточиться на поиске внутренних теоретических механизмов, лежащих в основе этих экспериментов, что позволит объяснить, почему и в каких контекстах данные проекты могут сработать.

Одной из проблем методов исследования является смешивание понятий экзогенности и гетерогенности, что приводит к некорректному их использованию. В качестве примера А. Дитон упоминает ряд исследований, где авторы пытаются оценить влияние международной помощи на экономический рост в развивающихся странах. Если мы добавляем в уравнение экономического роста наряду с традиционными факторами, такими как ВВП на душу населения прошлого периода, доля инвестиций в ВВП, оценка человеческого капитала, долю объема международной помощи в ВВП, то возникает много вопросов: если международная помощь инвестирована в экономику, не отражено ли это уже в показателе инвестиций? Имеет ли значение целевое назначение помощи - для борьбы с бедностью, для развития инфраструктуры, вакцинации, преодоления стихийных бедствий? Имеет ли международная помощь наряду с положительным отрицательное влияние, такое как вытеснение частных инвестиций, подрыв работы локальных институтов, стимулирование рентоориентированного поведения и коррупции? Даже если абстрагироваться от этих вопросов и воспринимать задачу в «медицинском» стиле, то помощь можно рассматривать как «лекарство», которое выдают разным странам в разных объемах. Но поскольку распределение «лекарства» не является случайным, то нам нужна инструментальная переменная для симулирования квазислучайности. Ряд исследователей предложили различные фиктивные переменные: размер населения, получение большего объема помощи франкофонными странами от Фран- 
ции и т.д. Предложенные переменные являются внешними, т. е. экзогенными, но это не означает, что они влияют на экономический рост исследуемых стран только через показатель международной помощи.

Еще один пример путаницы с внешними факторами и гетерогенностью - влияние лотереи, определяющей службу во Вьетнаме, на дальнейшие заработки призывников (Angrist, 1990). Даже случайные числа (номера лотерейного билета), которые выступают здесь независимыми переменными, не могут быть экзогенными, потому что параметр ошибки в уравнении дохода ветеранов зависит от оценки индивидуальной отдачи у каждого человека от обучения, что, в свою очередь, может влиять на то, поехал ли призывник во Вьетнам или нет $^{76}$. Раз норма прибыли от образования может влиять на отбор участников войны во Вьетнаме, то это является нарушением экзогенности (Blundell, Costa Dias, 2009).

На первый взгляд кажется, что многие проблемы можно преодолеть в микроэкономических исследованиях, но это не всегда так. В частности, А. Банерджи и Э. Дюфло, специалисты в области РКИ, очень высоко оценили результаты, полученные Дж. Ангристом и В. Лави в рамках естественного эксперимента, который позволил оценить влияние размера класса на успеваемость учеников (Angrist, Lavy, 1999). Во многих странах школы при формировании размера класса следуют правилу Маймонида, которое гласит, что его оптимальный размер не может превышать 40 чел. ${ }^{77}$. Таким образом, правило выступает стимулом квазиэкспериментальной вариации в данных и служит основой для предсказывания размера класса, который является инструментальной переменной для оценки успеваемости учеников. Полученные результаты, в отличие от представленных в рам-

${ }^{76}$ Фактически в данном исследовании оцениваются в группе воздействия люди, которые теоретически поедут во Вьетнам в результате отбора через лотерею. На практике существуют группы, затрудняющие получение релевантных результатов: волонтеры; те, чьи перспективы на рынке труда низки и они бы служили в любом случае; те, кто не стал бы служить ни в коем случае, а пошел бы в колледж, уехал в Канаду; те, кто не прошел медицинскую комиссию, и т. д.

77 Таким образом, если набрали 41 ученика в первые классы, то один класс будет состоять из 20 человек, а второй - из 21 . ках эконометрической оценки методом наименьших квадратов, демонстрируют, что ученики в маленьких классах учатся лучше.

Какие проблемы с этим исследованием? Во-первых, гетерогенность: мы можем оценить только средний эффект от попадания детей в класс меньшего размера. Вовторых, проблема рандомизации: вполне возможно, что процесс отбора детей по классам не является случайным ${ }^{78}$. В частности, исследование в Чили отбора детей в разные классы по правилу Маймонида подтверждает гипотезу, что попадание детей в маленькие классы неслучайно ${ }^{79}$. В частных школах Чили, где изучалось влияние размера класса на успеваемость, в маленьких классах оказывались дети более богатых и образованных родителей, сильнее мотивированных следить за успехами своего ребенка в школе и помогать ему.

Поддерживают аргументы Дитона и другие исследователи: использование инструментальных переменных часто подменяет поиск и идентификацию интересующей нас переменной неким «эффектом», который трудно потом интерпретировать (Heckman, Urzua, 2010). Возможно ли, что мы прикрываем неспособность эмпирических данных давать нам ответы на вопросы более сложными статистическими процедурами по их обработке в попытке получить из них то, чего там нет?

Г. Имбенс, отвечая на критику экспериментальных и квазиэкспериментальных исследований, утверждает, что инструментальные переменные позволяют обосновать внутреннюю валидность полученной оценки, что важно как для уточнения описания характеристик исследуемой группы лиц, так и для повышения доверия к эмпирическому направлению в экономике в целом (Imbens, 2010). Более того, современные исследования в этом направлении позволяют усовершенствовать и повысить точность оценки структурных моделей, т. е.

78 Во многих школах Беларуси тоже нет случайности в распределении учеников по классам. Иногда практикуется отбор по классам в зависимости от успеваемости детей или результатов вступительных тестов: в класс «А» попадают ученики с лучшими оценками, в класс «Б» средними и т. д.

79 Urquiola M., Verhoogen E. 2009. Class Size Caps, Sorting, and the Regression-Discontinuity Design. American Economic Review. Vol. 99. No 1. PP. 179-215. 
имеет место обогащение других подходов к анализу экономических явлений и процессов. Те же вопросы, которые поддаются экспериментальному анализу, должны быть исследованы именно таким способом в первую очередь, так как существует неоспоримое преимущество в получении эмпирических данных непосредственно, их надежность очень высока благодаря правильному дизайну и рандомизации.

Имбенс подчеркивает, что приоритет внутренней валидности над внешней есть и должен быть, т. е. достоверная оценка среднего эффекта для субпопуляции предпочтительнее оценки среднего эффекта для целевой группы населения с низкой достоверностью. Это согласуется с данными биомедицинской литературы. Хотя и примат внутренней валидности над внешней часто подвергается критике, среди исследователей и практиков нет поддержки перехода к системе, в которой исследования с низкой внутренней валидностью будут доминировать при принятии решений по экономической политике.

Д. Кард, осознавая слабые места методологии своих исследований, опубликовал статью, где рассматривает оценки отдачи от обучения и исследует, как выбор инструментов приводит к различным средним оценкам для разных подгрупп населения (Card, 1999). Он предложил, каким образом, учитывая неявный отбор, данные из различных исследований могут сравниваться между собой и быть обобщены. Дальнейшие исследования в этом направлении показали, что оценки, полученные при применении инструментальных переменных и ряда других эконометрических подходов, часто численно эквивалентны, т. е. выбор между этими оценками не важен для оценки эффектов ${ }^{80}$. Авторы предполагают, что различия между структурными оценками и оценками инструментальных переменных нередко возникают из-за разногласий по поводу целевого параметра, а не из-за различий в функциональной форме методов.

В настоящее время широко обсуждаются методологические подходы, которые помогли бы экспериментальным исследо-

${ }^{80}$ Kline P., Walters C. 2019. On Heckits, LATE, and Numerical Equivalence. Econometrica. Vol. 87. No 2. PP. 677-696. ваниям стать еще надежнее, так как часто возникают проблемы, связанные с: недостаточно большой выборкой; шумными данными; процедурой отбора; слабыми инструментальными переменными, искажающими результаты. Как и все другие отрасли научного знания, экспериментальная экономика переживает кризис репликации, т. е. невоспроизводимости ранее полученных результатов ${ }^{81}$. Это связано, в частности, с проблемой искажений, вызванных сложившейся практикой отбора статей для публикации, когда гораздо легче опубликовать статью со статистически значимыми результатами ${ }^{82}$. Это порождает стимулы для исследователей заниматься так называемым «хакингом значимости» (p-hacking) - завышением статистической значимости, чтобы преодолеть порог $p<0,005$. Заметить и осознать масштаб этой проблемы помогли метаисследования, которые позволяют проанализировать большое количество исследований на одну и ту же тему. В частности, Кард и Крюгер обнаружили проблему публикационных искажений на примере литературы, касающейся исследований минимальной заработной платы ${ }^{83}$.

Следует отметить, что подобные фальсификации обработки данных чаще встречаются при использовании инструментальных переменных и в естественных экспериментах, чем при проведении РКИ, так как стандарты последних стали строже и лучше прописаны. Введение требования

${ }^{81}$ Например, в результате перепроверки 100 статей по психологии удалось подтвердить только $39 \%$ их результатов (Baker M. 2015. Over Half of Psychology Studies Fail Reproducibility Test. URL: https://www.nature.com/articles/ nature.2015.18248). А метаисследование в области медицины, проведенное в 2012 г., смогло воспроизвести лишь $11 \%$ результатов из проанализированных 53 статей. Что касается экономических исследований, то К. Камерер и его соавторы повторили 18 лабораторных экспериментов, результаты которых были опубликованы в American Economic Review и Quarterly Journal of Economics в период с 2011 по 2014 г.: 39\% этих результатов не удалось воспроизвести. URL: https:/ /joachimvosgerau.files.wordpress.com/2018/09/camerer-et-al2018-nature-hb.pdf

${ }^{82}$ На самом деле, проблема искажений при публикации исследований еще глубже. Журналы охотнее принимают статьи, которые: имеют положительные и значимые результаты и больше цитируются; от известных авторов, работающих в рамках привычных экономических методик; оригинальные исследования, а не перепроверки ранее проведенных исследований.

${ }^{83}$ Card D., Krueger A. 1995. Time-Series MinimumWage Studies: A Meta-analysis. American Economic Review. Vol. 85. No 2. PP. 238-243. 
предварительной регистрации исследований перед их проведением позволяет бороться с умышленным изменением данных: гипотезы, методы и выборка указываются заранее и не могут быть изменены по ходу исследования. Свободный доступ к самым первичным данным дает всем заинтересованным лицам возможность провести перепроверку полученных данных и облегчает репликацию исследований ${ }^{84}$. Все это позволяет утверждать, что с течением времени качество таких исследований будет только расти.

Эмпирический поворот в экономических исследованиях на примере работ Д. Карда, Д. Ангриста и Г. Имбенса демонстрирует, что с применением новых методов анализа данных существует возможность проверки устоявшихся теоретических гипотез и выявления и описания новых взаимосвязей, что ранее было неосуществимо. Наращивание исследований в данном направлении внушает надежду на то, что не только экономическая теория будет лучше отражать экономическую действительность, но и экономическая политика станет более обоснованной, точной, эффективной.

\section{СПИСОК ЛИТЕРАТУРЫ (REFERENCES)}

Altonji J., Card D. 1991. The Effects of Immigration on the Labor Market Outcomes of LessSkilled Natives. Immigration, Trade, and the Labor Market. Chicago: University of Chicago Press. PP. 201-234.

Angrist J. 1990. Lifetime Earnings and the Vietnam Era Draft Lottery: Evidence from Social

${ }^{84}$ Осенью 2021 г. широкое обсуждение получило выявленное манипулирование первичными данными в известном исследовании о нечестности поведения (Shu L., Mazar N., Gino F., Ariely D., Bazerman M. 2012. Signing at the Beginning Makes Ethics Salient and Decreases Dishonest Selfreports in Comparison to Signing at the End. URL: https:// www.pnas.org/content/109/38/15197). На основании результатов этой влиятельной статьи многие компании включали в свои договоры (в начале документа) пункты, где клиенты давали обещание предоставить точные данные, что предположительно сокращало вероятность их нечестного поведения. После провала авторов оригинальной статьи и других ученых реплицировать данное исследование более глубокий анализ данных показал, что они были подделаны (URL: https://datacolada.org/98).
Security Administrative Records. American Economic Reviеш. Vol. 80. No 3. PP. 313-336.

Angrist J., Azoulay P., Ellison G., Hill R., Lu S.F. 2017. Economic Research Evolves: Fields and Styles. American Economic Review. Vol. 107. No 5. PP. 293-297.

Angrist J., Azoulay P., Ellison G., Hill R., Lu S. F. 2020. Inside Job or Deep Impact? Extramural Citations and the Influence of Economic Scholarship. Journal of Economic Literature. Vol. 58. No 1. PP. 3-52.

Angrist J., Krueger A. 1991. Does Compulsory Schooling Attendance Affect Schooling and Earnings? Quarterly Journal of Economics. Vol. 106. No 4. PP. 976-1014.

Angrist J., Krueger A. 1994. Why Do World War II Veterans Earn More than Nonveterans? Journal of Labor Economics. Vol. 12. No 1. PP. 74-97.

Angrist J., Lavy V. 1999. Using Maimonides' Rule to Estimate the Effect of Class Size on Scholastic Achievement. Quarterly Journal of Economics. Vol. 114. No 2. PP. 533-575.

Angrist J., Pischke J. 2010. The Credibility Revolution in Empirical Economics: How Better Research Design Is Taking the Con out of Econometrics. Journal of Economic Perspectives. Vol. 24. No 2. PP. 3-30.

Blundell R., Costa Dias M. 2009. Alternative Approaches to Evaluation in Empirical Microeconomics. Journal of Human Resources. Vol. 44. No 3. PP. 565-640.

Card D. 1990. The Impact of the Mariel Boatlift on the Miami Labor Market. Industrial and Labor Relations Review. Vol. 43. No 2. PP. 245-257.

Card D. 1992a. Using Regional Variation in Wages to Measure the Effects of the Federal Minimum Wage. Industrial and Labor Relations Review. Vol. 46. No 1. PP. 22-37.

Card D. 1992b. Do Minimum Wages Reduce Employment? A Case Study of California, 1987-89. Industrial and Labor Relations Review. Vol. 46. No 1. PP. 38-54.

Card D. 1996. The Effect of Unions on the Structure of Wages: A Longitudinal Analysis. Econometrica. Vol. 64. No 4. PP. 957-979.

Card D. 1999. The Causal Effect of Education on Earnings. URL: https://davidcard.berkeley.edu/ papers/causal_educ_earnings.pdf

Card D. 2001a. Immigrant Inflows, Native Outflows, and the Local Labor Market Impacts of Higher Immigration. Journal of Labor Economics. Vol. 19. No 1. PP. 22-64.

Card D. 2001b. The Effect of Unions on Wage Inequality in the U.S. Labor Market. Industrial and Labor Relations Review. Vol. 54. No 2. PP. 296-315.

Card D., Chetty R., Weber A. 2007. Cashon-Hand and Competing Models of Intertemporal 
Behavior: New Evidence from the Labor Market. Quarterly Journal of Economics. Vol. 122. No 4. PP. 1511-1560.

Card D., Lemieux T., Riddell C. 2004. Unions and Wage Inequality. Journal of Labor Research. Vol. 25. PP. 519-559.

Card D., Krueger A. 1992a. Does School Quality Matter? Returns to Education and the Characteristics of Public Schools in the United States. Journal of Political Economy. Vol. 100. No 1. PP. 1-40.

Card D., Krueger A. 1992b. School Quality and Black-White Relative Earnings: A Direct Assessment. Quarterly Journal of Economics. Vol. 107. No 1. PP. 151-200.

Card D., Krueger A. 1994. Minimum Wages and Employment: A Case Study of the Fast-Food Industry in New Jersey and Pennsylvania. American Economic Review. Vol. 84. No 4. PP. 772-793.
Deaton A. 2010. Instruments, Randomization, and Learning about Development. Journal of Economic Literature. Vol. 48. PP. 424-455.

Dunning T. 2012. Natural Experiments in the Social Sciences: A Design-Based Approach. Cambridge, UK: Cambridge University Press. 380 p.

Imbens G. 2010. Better LATE than Nothing: Some Comments on Deaton (2009) and Heckman and Urzua (2009). Journal of Economic Literature. Vol. 48. No 2. PP. 399-423.

Katz L., Krueger A. 1992. The Effect of the Minimum Wage on the Fast-Food Industry Industrial and Labor Relations Review. Vol. 46. No 1. PP. 6-21.

Harrison G., List J. 2004. Field Experiments. Journal of Economic Literature. Vol. 42. No 4. PP. 1009-1055.

Heckman J., Urzua S. 2010. Comparing IV with Structural Models: What Simple IV Can and Cannot Identify. Journal of Econometrics. Vol. 156. PP. 27-37.

\title{
HOW ECONOMIC VARIABLES ARE RELATED? SEARCH FOR ANSWERS THROUGH NATURAL EXPERIMENTS
}

\author{
Victor Vorobiev ${ }^{1}$, Aliaksandr Krauchanka ${ }^{2}$, Tatiana Maibarada ${ }^{1,2}$
}

\author{
Authors affiliation: ${ }^{1}$ Belarusian State Economic University (Minsk, Belarus); \\ ${ }^{2}$ Center of Behavioral Economics «MeMicroMacro» (Minsk, Belarus).
}

Corresponding author: Victor Vorobiev (vorobiev_v@bseu.by).

ABSTRACT. The contribution of D. Card, J. Angrist and G. Imbens to the development and application of new ways to identify cause-and-effect relationships in economic science is presented. Conducting natural experiments allowed Card, in particular, to empirically identify and quantify the impact of the level of the minimum wage and immigration on the labour market, which proved the productivity of this approach. Angrist and Imbens took the use of instrumental variables to the next level by assessing the local average treatment effects, which allowed the overcoming of a number of methodological problems. The key scientific works of the Laureates, the peculiarities of their methodology and its criticism, and the non-economic application of their experiments are considered.

KEYWORDS: natural experiments, design-based approach, local average treatment effect (LATE), instrumental variables, labour market, minimum wage policy, immigration, returns to education, unions.

JEL-code: B41, C90, I26, J21, J51, J61, J65, R23.

DOI: $10.46782 / 1818-4510-2021-4-4-26$

Received 16.11.2021 